Vol. 3, No. 1, 2021

https://doi.org/10.23939/jtbp2021.01.035

Tetiana Kropyvnytska ${ }^{1}$, Iryna Heviuk ${ }^{2}$, Roksolana Stekhna ${ }^{3}$, Oksana Rykhlitska ${ }^{1}$, Lidiia Deschenko ${ }^{1}$

\title{
EFFECT OF LIMESTONE POWDER ON THE PROPERTIES OF BLENDED PORTLAND CEMENTS
}

\author{
Lviv Polytechnic National University, \\ ${ }^{1}$ Department of building production \\ tkropyvnytska@ukr.net, \\ ${ }^{2}$ PJSC "Ivano-Frankivskcement" \\ headcl@ifcem.if.ua, \\ Ivano-Frankivsk National Technical University of Oil and Gas, \\ ${ }^{3}$ Department of Construction and Civil Engineering \\ semeniv.roksolana@gmail.com
}

CC Kropyvnytska T., Heviuk I., Stekhna R., Rykhlitska O., Deschenko L., 2021

\begin{abstract}
The article shows relation between sustainability and cement manufacture that can be obtained by replacement of clinker with limestone additive. This decrease the use of energy resources and reduce $\mathrm{CO}_{2}$ emissions in cement production. The issue of partial Portland cement clinker substitution by finely ground limestone in the production of market-oriented cements type CEM II is solved on the cement plant PJSC "Ivano-Frankivsk Cement". The indexes of physical-mechanical tests of certified Portland limestone cement with high early strength CEM II/A-LL 42.5 R produced by PJSC "IvanoFrankivsk Cement0 are given. Finely dispersed limestone in Portland-composite cements with slag promotes more complete synergic effect. It is established, that rapid-hardening blended Portland cements with limestone powder provides technological, technical, ecological and economic effects in the production of prefabricated and monolithic reinforced concrete.

Key words: Portland limestone cement, limestone powder, dispersion, high early strength, physical and mechanical properties
\end{abstract}

\section{Introduction}

Currently, there are changes in the nomenclature of produced and consumed cements in the EU countries for environmental and economic reasons. In recent years, the production of Portland cement type CEM II strength class 42.5 has increased. A clear illustration of this trend is the statistics on the use of cements CEM I, CEM II, CEM III of different strength classes in Germany (Schneider, 2019; Scrivener, 2018). Thus, in 2000, the highest percentage of cement $(60.1 \%)$ was produced in strength class 32.5 , while the production of cements in strength class 42.5 was $33.4 \%, 1.8$ times less. At the same time, in 2017, there was a significant increase in the production of high-quality cements: the strength class 42.5 increased to $60.7 \%$, in particular the strength class 52.5 increased from 6.5 to $17 \%$. Portland cements type CEM II with additives played a dominant role. Due to the shortage of high-quality granular blast furnace slag (GBFS) in some EU countries, the task of its full or partial replacement is set. This leads to the need to reduce the GBFS content in the composition of cements. Therefore, according to CEMBUREAU in the EU, since 2010, there has been an increase in production of Portland limestone cement CEM II/L, LL, and sales of Portland cement without additives CEM I has decreased almost twice (Cembureau; Giergiczny, 2008). Therefore, the development of rapid setting Portland cements with low 
clinker factor, which provide the creation of advanced technologies of high-quality concrete contributes to the implementation of the strategy of low-carbon development in Ukraine.

\section{Review of scientific sources and publications}

The cement industry worldwide is facing growing challenges in conserving material and energy resources, as well as reducing its $\mathrm{CO}_{2}$ emissions (Biernacki, 2017; Andrew, 2018). The reduction of the clinker factor remains a key priority in cement. CEM I cement is being increasingly replaced by CEM II cement which, in addition to the clinker, also contain other main constituents. Grinding efficiency is important for all comminution processes in a cement plant. While the requirements are basically the same in all cases, cement grinding has a special additional focus, which is workability of the final product and its strength development. Both parameters not only depend on the particle size but to a large degree on the size distribution (Sroda, 2017; Ludwig, 2012).

The main problem for processing is to prepare and mix suitable combinations of clinker and interground additives so that the performance lies in the same range as comparable to Portland cements. Most cement plants use granulated blast furnace slag and fly ash as a mineral additives and limestone as microfillers. At the same time with increasing content of granulated blast furnace slag reduces cement grindability. The slope of the blast furnace slag and for the clinker is 0.9 , for the readily grindable limestone -0.5 . Such differences in grindability must be taken into account during intergrinding as the fine grinding of the various cement constituents does not take place individually or independently from one another but is dictated by the technical parameters of the mill and classifier as well as by the grindability of the cement constituents. These differences in grindability also affect the overall particle size distribution of the cement (Ludwig, 2012; Müller, 2014).

The reason of the increase in the production of Portland cement with the addition of limestone is due to the fact that limestone is obtained from its own quarries of cement plants and is one of the most widely available raw materials (Sanytskyy, 2019; Zach, 2009). Completely different conditions can be expected in the combination of clinker with limestone, e.g. in Portland limestone cement. The limestone builds up in the finer size fractions during intergrinding with clinker because limestone is easier to grind. According to the technology of separate grinding and subsequent mixing the degree of homogeneity of highly dispersed system with limestone differs fundamentally. Ultrafine filler added during cement milling is thoroughly mixed with grinded clinker. It provides its maximum uniform distribution in the mass of the cement powder. Particles of microfiller that are placed between individual grains of cement increase their adsorption, reduce porosity and promote compaction of cement stone structure. The most complete microfilling effect is with increasing the volume concentration of ultrafine additives when the porosity of a cement stone decreases and density of its structure increases. In contrast to intergrinding, separate grinding followed by mixing of the components provides a uniform distribution of clinker and blast furnace slag over the entire particle size range, optimization of particle size distribution of the obtained composite Portland cement, improve technological, physical and mechanical properties of mortars and concretes based on this binder (Kruts, 2018; Sanytskyy, 2010).

The separate grinding is more efficient and such Portland-limestone cements and Portlandcomposite cements ("green" cements) are characterized by higher compressive strength and determined by ecological and economic factors (Kropyvnytska, 2013; Sanytskyy, 2015). As a result, the development of Portland cements with the addition of limestone is of considerable practical interest, as if it is characterized by technical, economic and environmental advantages.

\section{The aims and objectives of the study}

The aim of the study is to investigate the influence of limestone powder of different dispersion on physical and mechanical properties of blended Portland cements. 
To achieve this goal the following tasks were solved:

- to study physical and mechanical properties of Portland limestone cement with high early strength CEM II/A-LL $42.5 \mathrm{R}$;

- to study the effect of limestone powder dispersion on the properties of Portland slag cements.

\section{Materials and methods}

Portland limestone cement CEM II/A-LL 42.5 R was obtained at PJSC "Ivano-Frankivskcement". The content of Portland cement clinker was 85-90 mass. \%, limestone - 15-10 mass. \%. Portland cement clinker with chemical composition (mass. \%: $\mathrm{CaO}-66.45 ; \mathrm{SiO}_{2}-20.84 ; \mathrm{Al}_{2} \mathrm{O}_{3}-5.36 ; \mathrm{Fe}_{2} \mathrm{O}_{3}-4.03$; $\mathrm{MgO}-0.75 ; \mathrm{SO}_{3}-0.87 ; \mathrm{K}_{2} \mathrm{O}-1.22 ; \mathrm{Na}_{2} \mathrm{O}-0.11$ ) was used in the investigations. Mineralogical composition of clinker is, mass. \%: $\mathrm{C}_{3} \mathrm{~S}-60.91 ; \mathrm{C}_{2} \mathrm{~S}-14.26 ; \mathrm{C}_{3} \mathrm{~A}-7.07 ; \mathrm{C}_{4} \mathrm{AF}-12.35$. Portland cements were used for research CEM I $42.5 \mathrm{R}\left(\mathrm{SSA}=3600 \mathrm{~cm}^{2} / \mathrm{g}\right)$, CEM II/A-S $42.5 \mathrm{R}\left(\mathrm{SSA}=3500 \mathrm{~cm}^{2} / \mathrm{g}\right)$, CEM III/A-S 32.5 $\mathrm{R}\left(\mathrm{SSA}=3450 \mathrm{~cm}^{2} / \mathrm{g}\right)$ and CEM II/B-S $32.5 \mathrm{R}\left(\mathrm{SSA}=3400 \mathrm{~cm}^{2} / \mathrm{g}\right)$ PJSC "Ivano-Frankivskcement". Limestone powder from Dubivetske quarry used as a mineral additive and microfiller. The limestone has 95.6 mass. \% content of $\mathrm{CaCO}_{3}$. Limestone belongs to the type $\mathrm{L}$ according EN 197-1:2011 in terms of total content of organic carbon. Limestone with different dispersion were used in research: limestone L $\left(\mathrm{SSA}=6900 \mathrm{~cm}^{2} / \mathrm{g}\right)$, limestone $\mathrm{L}^{*}\left(\mathrm{SSA}=9800 \mathrm{~cm}^{2} / \mathrm{g}\right)$, limestone $\mathrm{L} * *\left(\mathrm{SSA}=10200 \mathrm{~cm}^{2} / \mathrm{g}\right)$. Standard polyfractional sand according EN 196-1 was used for cements testing.

Study of fractional composition and grinding fineness of cements was carried out by sieve analysis and by determination of the specific surface area by Blaine. The particle size distribution of Portland cement CEM II/A-LL 42.5 R was measured by laser granulometer Mastersizer 3000. In order to quantify the PSD by surface area of cementitious materials, the coefficient of incremental surface area $\left(\mathrm{K}_{\text {isa }}\right)$ was calculated according to a special methodology (Sanytskyy, 2018). This coefficient is defined as the product of $\mathrm{A} / \mathrm{V}$ for a given particle size (the ratio of the surface area of the particle to its volume, $\mu \mathrm{m}^{-1}$ ) to the content of a fraction by volume based on laser granulometry data.

\section{Results of investigation}

The issue of partial Portland cement clinker substitution by finely ground limestone in the production of market-oriented cements of type CEM II is solved on the cement plant PJSC "IvanoFrankivskcement", It gives a possibility to produce blended "green" cements through the implementation of intergrinding and separate grinding of clinker and additives in mills with up-to-date separators. Given the significant growth in the EU of Portland cement production with the addition of limestone CEM II/L,LL, the effect of limestone on the properties of blended cements was investigated. Limestone, compared to clinker or GBFS, is a soft material with high grinding capacity. Limestone provides a fine fraction $(<5 \mu \mathrm{m})$ in the cement after co-grinding with Portland cement clinker. It increases the activity of Portland cement by optimizing the particle size distribution with a wider range of grain distribution by fractions and thus reducing the volume of voids between clinker grains.

A comprehensive assessment of the dispersion of Portland limestone cement found that the specific surface area is $\mathrm{SSA}=4300 \mathrm{~cm}^{2} / \mathrm{g}$, the residue on the sieve $\mathrm{A}_{0045}=5.5 \%$. As can be seen from the Table 1 , the volume and surface area mean diameters of the Portland limestone cement.

Table 1

Granulometric composition of Portland limestone cement

\begin{tabular}{|c|c|c|c|c|c|c|c|c|c|}
\hline $\begin{array}{c}\varnothing<1 \\
\mu \mathrm{m}, \%\end{array}$ & $\begin{array}{c}\varnothing<5 \\
\mu \mathrm{m}, \%\end{array}$ & $\begin{array}{c}\varnothing<10 \\
\mu \mathrm{m}, \%\end{array}$ & $\begin{array}{c}\varnothing<20 \\
\mu \mathrm{m}, \%\end{array}$ & $\begin{array}{c}\varnothing<45 \\
\mu \mathrm{m}, \%\end{array}$ & $\begin{array}{c}\mathrm{D}[3 ; 2] \\
\mu \mathrm{m}\end{array}$ & $\begin{array}{c}\mathrm{D}[4 ; 3] \\
\mu \mathrm{m}\end{array}$ & $\begin{array}{c}\mathrm{D}_{\mathrm{v}}(10) \\
\mu \mathrm{m}\end{array}$ & $\begin{array}{c}\mathrm{D}_{\mathrm{v}}(50) \\
\mu \mathrm{m}\end{array}$ & $\begin{array}{c}\mathrm{D}_{\mathrm{v}}(90) \\
\mu \mathrm{m}\end{array}$ \\
\hline 9.01 & 31.92 & 48.72 & 66.51 & 94.50 & 2.92 & 18.4 & 1.26 & 11.8 & 45.6 \\
\hline
\end{tabular}


Volume mean diameter $\mathrm{D}[4 ; 3]$ corresponds to $18.4 \mu \mathrm{m}$. The surface area mean diameter $\mathrm{D}[3 ; 2]$ corresponds to $18.4 \mu \mathrm{m}$ to $2.92 \mu \mathrm{m}$. The effective diameters Dv (10), Dv (50) and Dv (90) are 1.26, 11.8 and $45.6 \mu \mathrm{m}$, respectively. The thin fraction of limestone helps to increase the plasticity of cement paste, and the other fractions - perform as microfiller, increasing the density of the cementitious matrix (Fig. 1,a). It should be noted that the specific surface area of Portland limestone cement CEM II/A-LL 42.5 R is determined mainly by the fine fraction of limestone, which is confirmed by the increased value of the coefficient on the specific surface area $\left(\mathrm{K}_{\mathrm{isa}}=9.43 \mu \mathrm{m}^{-1} \mathrm{vol} . \%\right)$ (Fig. $\left.1, b\right)$.

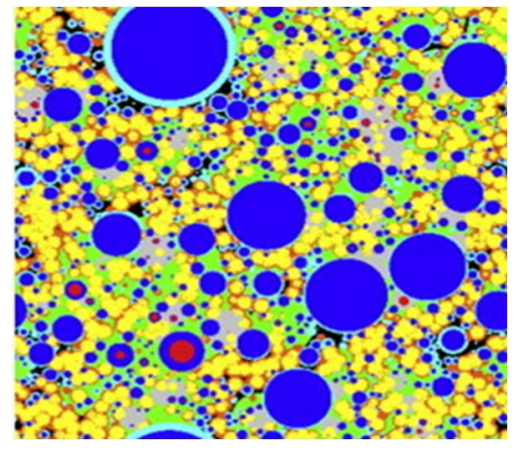

$a$

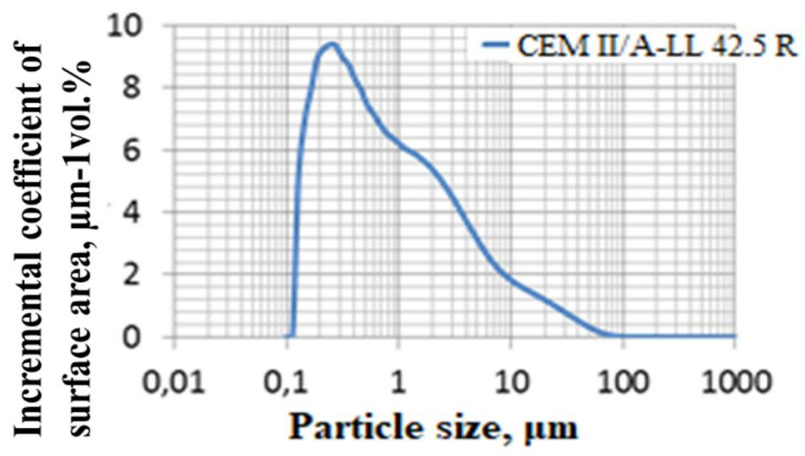

$b$

Fig. 1. Model of distribution of clinker and limestone particles (a) and PSD by surface area (b) of Portland limestone cement CEM II/A-LL 42,5 R

Comparative physical and mechanical tests of Portland limestone cement were provided according to DSTU B V.2.7-187 with $\mathrm{W} / \mathrm{C}=0.39$ on the basis of monofractive sand, and also according to DSTU B EN 196-1 on the basis of polyfractional sand, which is more in line with the requirements for ready-mixed concrete. Thus, workability of cement-sand mixture is 116 and $190 \mathrm{~mm}$ according to testing by DSTU B V.2.7-187 and DSTU B EN 196-1, respectively. It indicates that this Portland cement provides improved consistency of concrete mixtures. The main properties of Portland limestone cement CEM II/A-LL 42.5 R, made on the basis of clinker of normalized mineralogical composition DSTU B EN 197-1:2015, are given in Table 2. The water demand of cement paste is 29.0\%, bleeding $-20.5 \%$ for Portland cement with limestone. It can be seen that the compressive strength after 2, 28 and 180 days is $34.6 \mathrm{MPa}, 45.8 \mathrm{MPa}$ and $56.2 \mathrm{MPa}$. It should be noted that the early strength of this cement corresponds to the strength of Portland cement without the additives CEM I 42.5 R.

Differential calorimetry method showed that the first exoeffect is $39.5 \mathrm{~mW} / \mathrm{h}$, the induction period is 1.4 hours for CEM II/A-LL $42.5 \mathrm{R}$. The second exoeffect is observed after 7.0 hours and corresponds to $4.67 \mathrm{~mW} / \mathrm{h}$. The heat of hydration after 24 and 96 hours is 234 and $328 \mathrm{~J} / \mathrm{g}$ respectively, and is at the level of Portland cement CEM I 42.5 R.

Table 2

\section{Physical and mechanical properties of Portland limestone cement with high early strength CEM II/A-LL 42.5 R}

\begin{tabular}{|c|c|}
\hline Properties & Results \\
\hline Specific surface area by Blaine, $\mathrm{cm}^{2} / \mathrm{g}$ & 4300 \\
\hline Water demand, \% & 29.0 \\
\hline Initial setting time, $\min$ & 140 \\
\hline Workability (flow value), mm & 190 \\
\hline Bleeding, $\%$ & 20.5 \\
\hline Compressive strength/flexural strength, days, MPa, after 2 & $34.6 / 5.7$ \\
\hline 7 & $26.2 / 6.9$ \\
\hline 28 & $45.8 / 9.8$ \\
\hline 180 & $56.2 / 11.0$ \\
\hline
\end{tabular}


To substantiate the possibility of wider use of limestone in mixed cements, a study of its effect on the physical and mechanical properties of slag-containing cements of type II was conducted. It was established that, the introduction of 10-20 mass. \% limestone to Portland cements CEM II/A-S 42.5 R, CEM II/A-S 32.5 R, CEM II/B-S 32.5 reduces the water consumption of the binder. There is an increase in early strength after mixing Portland cements CEM II/A-S 42.5 R and CEM II/A-S 32.5 R with 10 mass. \% limestone. The early strength after 2 days is 27.7 and $13.9 \mathrm{MPa}$ respectively. Compressive strength decreases at all curing times with the introduction of limestone to Portland cement CEM II/B-S 32.5. Dispersion of limestone significantly increases during grinding. Part of Portland cements CEM I and CEM II/A-S was replaced by limestone with different specific surface area (L, L*, L**) by technology of separate grinding. Partial replacement in volume of cement by limestone powder of 6900 to $10200 \mathrm{~cm}^{2} / \mathrm{g}$ specific area resulted in an enhancement in fluidity and a reduction of the yield stress. As seen from Fig. 2, $a$, the addition of $10-20$ mass. $\%$ of ultrafine limestone powder $L^{* *}$ provides strength increase of fine-grained concrete $(\mathrm{C}: \mathrm{S}=1: 2)$ in all terms of hardening at 8.7-5.2\% compared to concrete based on Portland cement CEM I. The same trend is observed with the addition of limestone (SSA=10200 $\mathrm{cm}^{2} / \mathrm{g}$ ) to the composition of Portland cement CEM II/A-S. After 365 days of hardening strength increases for all compositions of fine-grained concretes based on CEM I and CEM II/A-S with ultrafine limestone meal. Fine-grained concretes based on CEM I and CEM II/A-S with the addition of 10 mass. \% of ultrafine limestone $\mathrm{L}^{* *}$ are characterized by highest strength which is respectively 85.7 and $82.1 \mathrm{MPa}$ (Fig. 2, b). It follows that according to the stoichiometry of reactions with the formation of hexagonal AFm-phases at a content of 19.3 mass. \% minerals can be used only 4.1 mass. \% fine calcium carbonate, and the rest acts as a microfiller, providing "the effect of fine powders" (Sanytskyy, 2019).

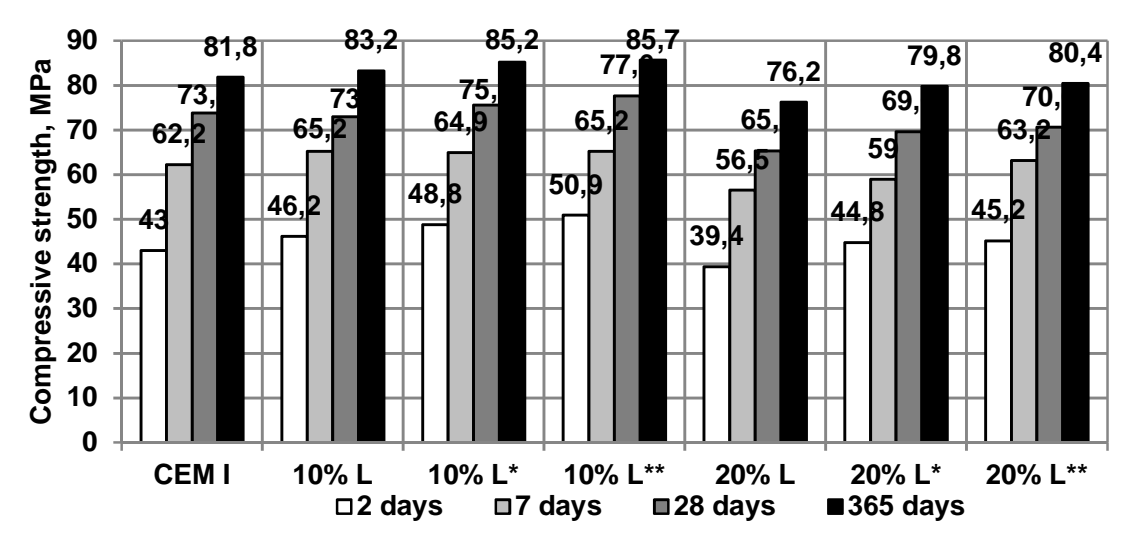

$a$

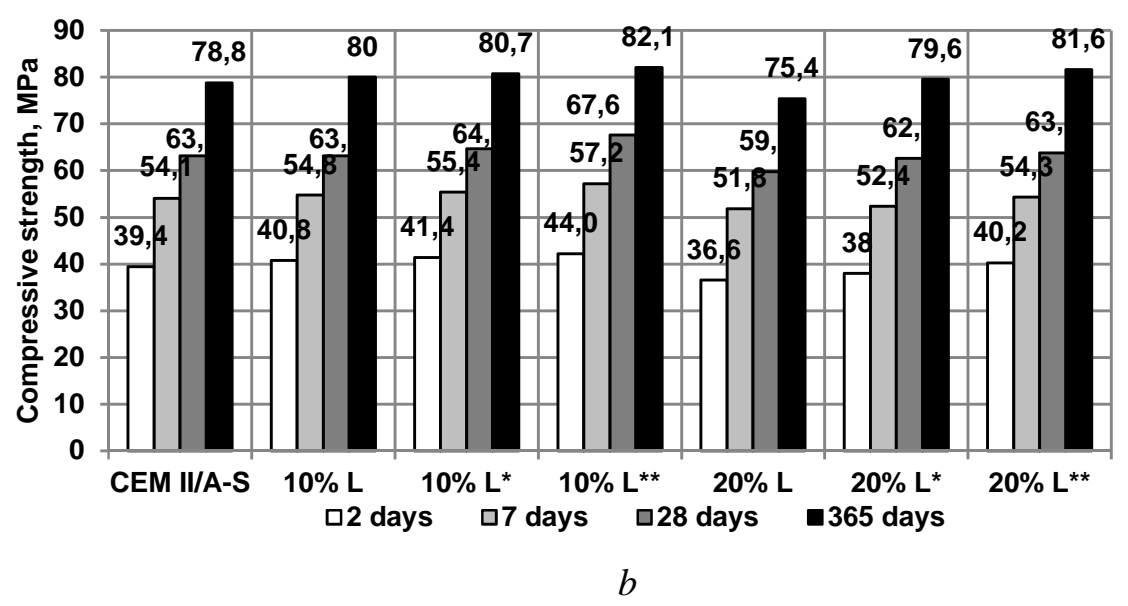

Fig. 2. Compressive strength of fine-grained concretes based on CEM I (a) and CEM II/A-S $(b)$ with addition of limestone of different dispersion 
Concrete based on Portland limestone cement (amount of cement is $350 \mathrm{~kg} / \mathrm{m}^{3}$ ) and superplasticizer were tested. Modified concrete mixes $(\mathrm{W} / \mathrm{C}=0.40)$ are characterized by higher workability and slump is $180 \mathrm{~mm}$ which allows to consider concrete to consistency class S4. Compressive strength after 28 days of hardening of modified concrete is $59.6 \mathrm{MPa}$ which corresponds to the strength class $\mathrm{C} 35 / 45$. Applying Portland cements containing limestone with low heat of hydration allows to decrease strain of concrete. Portland limestone cement CEM II/A-LL $42.5 \mathrm{R}$ can be used for the manufacture of self-compacting concrete and ensure a high rate of concrete hardening. Composite Portland cement with addition of limestone CEM II/A,B-M(S-LL) could be used for construction of reinforced concrete bridges, manufacturing massive concrete structures, pools, precast reinforced concrete. Low chloride content can increase operating life of reinforced concrete due to the decrease of reinforcement corrosion in concrete. The fine limestone increases the density of concrete and significantly reduces efflorescence on its surface due to the reduction of the capillary effect. High plasticity of concrete mixes based on CEM II/A-LL allows for the creation of irregular and free-form shapes, providing an exterior appearance, creating a unique shape, a monolithic building.

\section{Conclusions}

In the cement industry of Europe, limestone is the most common cement-substituting material, which participates in hydration reactions and is an active mineral additive relative to the aluminate phase and also acts as a microfiller.

PJSC "Ivano-Frankivskcement" organized industrial production of Portland limestone cement with high early strength CEM II/A-LL 42.5 R, which has a light color, used for the manufacture of concrete grades $\mathrm{C} 25 / 30 \ldots \mathrm{C} 50 / 60$, in the production of load-bearing structures of all types of construction, provides a smooth surface to products. The efficiency of using Portland limestone cement CEM II/A-LL $42.5 \mathrm{R}$ and blended Portland composite cement CEM II/A-M(S-L) $42.5 \mathrm{R}$ with high early strength is manifested primarily in increasing the workability of concrete mixtures and reducing their water separation, increasing the early strength of concrete, as well as accelerated hardening.

The experience of wide use of Portland limestone cement in the EU countries shows that it is possible to obtain high-quality concrete on the basis of Portland cements with the addition of limestone. This concrete is characterized by improved physical and mechanical properties and lighter color.

\section{References}

Schneider, M. (2019). The cement industry on the way to low-carbon future. Cement and Concrete Research, 124, 1-19. doi:10.1016/j.cemconres.2019.105792

Scrivener, K., John, V., \& Gartner, E. (2018). Eco-efficient cements:Potential economically viable solutions for a low- $\mathrm{CO}_{2}$ cement-based materials industry. Cement and Concrete Research, 114, 2-26. doi: 10.1016/j.cemconres.2018.03.015

Cements for low-carbon Europe - Cembureau. https://cembureau.eu/media/1501/cembureau_cementslow carbon europe.pdf

Giergiczny, Z., \& Sokołowski, M. (2008). Cement z dodatkiem kamienia wapiennego CEM II/A,B-LL właściwości i możliwości zastosowania w budownictwie. Budownictwo, Technologie, Architektura, 3, 54-57.

Biernacki, J. J., Bullard, J. W., Sant, G., Brown, K., Glasser, F. P., Jones, S., ... Prater, T. (2017). Cements in the 21st Century: Challenges, Perspectives, and Opportunities. Journal of the American Ceramic Society, 42. doi.org/10.1111/jace. 14948

Andrew, R. M. (2018). Global $\mathrm{CO}_{2}$ emissions from cement production. Earth Syst. Sci. Data, 10, $195-217$. doi.org/10.5194/essd-10-195-2018

Sroda, B. (2017). Potencial przemyslu cementowego w redukcji emisji $\mathrm{CO}_{2}$. Budownictwo, technologie, architektura, 3(79), 72-74.

Ludwig, H.-M. (2012). Future cements and their properties. Cement International. Verlag Bau + Technik GmbH, 4, 81-89.

Müller, Ch., Palm, S., Graubner, C.-A., Proske, T., Hainer, S., Rezvani, M., Reuken I. (2014). Cements with a high limestone content - durability and practicability. Cement International, 12(2), 78-85.

Sanytskyy, M., Kropyvnytska, T., \& Geviuk, I. (2019). Shvydkotverdnuchi portlandcementy z dobavkoyu vapniaku. Budivelni materialy ta vyroby, 1/2(100), 34-37 (in Ukrainian). 
Zach, J., Schorik, V., \& Petranek V. (2009). Possibilities of utilization of finely ground limestone for cement CEM II as substitution to blast furnace slag. 17. ibausil, Weimar, Tagungsband, 2, 117-122.

Kruts, T. M., Horpynko O. F., Geviuk, I. M., Sanytskyy, M. A., \& Kropyvnytska, T. P. (2018). Vysokoyakisni shvydkotverdnuchi portlandcementy vyrobnyctva PrAT "Ivano-Frankivskcement". Budivelni materialy ta vyroby, 1/2(97), 34-37 (in Ukrainian).

Sanytskyy, M., Sobol, Kh., \& Markiv, T. (2010). Modyfikovani kompozycijni cementy. Lviv: Vydavnytstvo Lvivskoj politehniky, 132 (in Ukrainian).

Kropyvnytska, T., Sanytskyy, M., \& Geviuk, I. (2013). Vplyv karbonatnyh dobavok na vlastyvosti Portland cementu kompozycijnogo. Lviv: Vydavnytstvo Lvivskoj politehniky : Teoriia i praktyka budivnyctva, 755, 214-220 (in Ukrainian).

Sanytskyy, M., Kruts, T., Kropyvnytska, T., \& Rusyn B. (2015). Sustainable Green Engineered Composites Containing Ultrafine Supplementary Cementitious Materials. 14th International Congress on the Chemistry of Cement, Beijing, China, 1, 265.10

Sanytskyy, M., Kropyvnytska, T., Kruts, T., Horpynko, O., \& Geviuk I. (2018). Design of rapid hardening quaternary zeolite-containing Portland-composite cements. Key Engineering Materials, 761, $193-196$. doi:10.4028/www.scientific.net/KEM.761.193.

Т. П. Кропивницька ${ }^{1}$, І. М. Гев'юк², Р. М. Стехна ${ }^{3}$, О. В. Рихліцька ${ }^{1}$, Л. В. Дещенко ${ }^{1}$

${ }^{1}$ Національний університет “Львівська політехніка", кафедра будівельного виробництва

2 ПрАТ "Івано-Франківськцемент"

${ }^{3}$ Івано-Франківський національний технічний університет нафти і газу, кафедра будівництва та енергоефективних споруд

\title{
ВПЛИВ ВАПНЯКУ НА ВЛАСТИВОСТІ ЗМІШАНИХ ПОРТЛАНДЦЕМЕНТІВ
}

\author{
(C) Кропивницька Т. П., Гев'юк I. М., Стехна Р. М., Рихліиька О. В., Дещенко Л. В., 2021
}

Проаналізовано досвід широкого використання портландцементів 3 добавкою вапняку в країнах ЄС. Показано, що нині значно збільшується випуск високомарочних цементів класу міцності 42,5 R. Дані CEMBUREAU свідчать, що у СС спостерігається збільшення випуску цементів 3 мінеральними добавками CEM II та портландцементів 3 добавкою вапняку CEM II/L,LL 3 високою ранньою міцністю класів 42,5 R та 52,5 R, а рівень продажу портландцементу без добавок СЕM I зменшився майже в два рази. В Україні провідним підприємством з виготовлення високоефективних портландцементів, зокрема з добавкою вапняку, є ПрАТ “Івано-Франківськцемент”. Використання сучасної технології помелу в замкненому циклі дає змогу одержувати широкий асортимент цементів шляхом як сумісного, так і роздільного помелу клінкеру і добавок у млинах із сепараторами останнього покоління. Наведено показники фізико-механічних випробувань сертифікованого портландцементу з вапняком з високою ранньою міцністю CEM II/A-LL 42,5 R ПрАТ “Івано-Франківськцемент”. 3 використанням сучасного лазерного аналізатора Mastersizer 3000 досліджено гранулометричний склад портландцементу з вапняком. Встановлено, що портландцемент CEM II/A-LL 42,5 R характеризується підвищеним вмістом тонкої фракції (Ø <5 мкм становить 31,92 \%), яка більшою мірою забезпечується добавкою вапняку. Встановлено, що введення 10 мас. \% тонкодисперсного вапнякового порошку (SSA=6900...10200 cм²/г) забезпечує збільшення міцності у всі терміни тверднення. Ефективність використання змішаних портландцементів 3 вапняком 3 високою ранньою міцністю проявляється передусім у підвищенні рухливості бетонних сумішей і зменшенні їх водовідділення, збільшенні ранньої міцності бетону, а також прискореному твердненні в умовах понижених додатних температур. Швидкотверднучі портландцементи 3 добавкою вапняку забезпечують технологічний, технічний та економічний ефекти під час виготовлення збірного та монолітного залізобетону.

Ключові слова: портландцемент $з$ добавкою вапняку, вапняковий порошок, дисперсність, висока рання міцність, фізичні та механічні властивості. 